\title{
Heterogeneity in the cyclical sensitivity of job-to-job flows
}

\author{
Sandra Schaffner
}

Received: 27 October 2009 / Accepted: 15 November 2010 / Published online: 21 January 2011

(C) Institut für Arbeitsmarkt- und Berufsforschung 2011

\begin{abstract}
Scarce empirical evidence exists for Germany regarding the cyclical aspects of worker reallocation. Furthermore, it is assumed that the cyclical influence on transition rates is the same for all demographic groups. However, one can expect that each subgroup is differentially influenced by the same cycle.

Therefore, we emphasize the heterogeneity of cyclical influences for different subgroups of workers, defined by age, gender and skills, and focus on job-to-job transitions which are, in fact, found to be the largest flows in the German labor market. The findings suggest that job-to-job transitions are procyclical. The empirical framework employed here allows demographic groups to vary in their cyclical sensitivity. Female and unskilled workers experience more pronounced swings than the core group of medium-skilled, medium-aged men. By contrast, the job-to-job transition rates of highskilled workers, old workers, as well as young workers are less influenced by cyclical behavior.
\end{abstract}

Keywords Labor force - Employment dynamics . Worker flows · Business cycle · Worker heterogeneity Job-to-job

JEL classification E32 $\cdot$ J63 $\cdot$ J64 $\cdot$ E24

Author website: http://www.rwi-essen.de/schaffner

S. Schaffner (

Rheinisch-Westfälisches Institut für Wirtschaftsforschung (RWI), Hohenzollernstrasse 1-3, 45128 Essen, Germany

e-mail: sandra.schaffner@rwi-essen.de

Tel.: +49-201-8149282

Fax: +49-201-8149200

\section{Heterogenität in der Konjunkturabhängigkeit von Job-zu-Job-Übergängen}

Zusammenfassung Die konjunkturellen Einflüsse auf die Dynamik am Arbeitsmarkt sind ein weit untersuchtes Feld der Literatur. Allerdings ist die empirische Evidenz für Deutschland noch sehr gering. Kluve et al. (2009) zeigen, dass sich die konjunkturellen Einflüsse für demografische Gruppen unterscheiden. Die vorliegende Studie ergänzt diese Analyse durch die Untersuchung der direkten Übergänge zwischen zwei Beschäftigungsverhältnissen. Diese sogenannten Job-to-Job-Flüsse sind die größten Flüsse in Deutschland. Die Ergebnisse zeigen für Westdeutschland, dass Job-to-Job-Übergänge prozyklisch sind. Dabei sind die Transitionen von Frauen und Geringqualifizierten volatiler als die anderer Gruppen. Im Gegensatz dazu sind die Übergangsraten hochqualifizierter, älterer oder jüngerer Arbeitnehmer weniger volatil als die der Kerngruppe mittelalter, mittelqualifizierter Männer.

\section{Introduction}

Germany has been suffering from high unemployment rates for the last two decades, accompanied by a low GDP growth. Especially in some regions of East Germany, the unemployment rate has persistently been higher than $20 \%$. In recent years, GDP growth has risen and unemployment has declined. Yet, people of different ages and different skill levels apparently benefit differently from this improved economic situation. This impression prompted Schmidt (2000) and, subsequently, Kluve et al. (2009) to examine, for different demographic groups, the heterogeneous cyclical sensitivity of unemployment rates and of transition intensities across labor-market states. These previous papers document that the 
heterogeneity of labor-market dynamics is substantial. They have not considered job-to-job flows, however, when calculating intensities of job losses and re-employment, although job-to-job transition rates are an important component of the German labor market.

In contrast to the above-mentioned studies which use the German Socioeconomic Panel, we use a very large micro dataset provided by the research institute of the Federal Employment Agency, the IAB employment subsample (IABS). The data allows us to distinguish job-to-job transitions on a daily basis. Besides heterogeneity between demographic groups which is controlled for, we take job tenure into account since Jung and Kuhn (2009) show that $75 \%$ of all quits are by workers with tenure of less than two years. In contrast to Schmidt (2000), the analysis pays particular attention to the question of whether the cyclical behavior of job-to-job transitions differs across demographic groups and tenure. Furthermore, the findings are compared to the sensitivity of other transition intensities. To compare the cyclical sensitivity between different transition rates, a similar approach is undertaken for the job-finding and job-loss rate.

The cyclical relationship is modeled for the core group of male, medium-aged, medium-skilled workers. The sensitivity of all other groups is then modeled as the deviation from this core group. Our results indicate that women and unskilled workers are more influenced in their job-tojob transition rate by the cycle than the core group. In contrast, high-skilled, young, or old workers are less influenced by the business cycle. However, the sensitivity is even reversed for women, young, and old workers regarding their job-loss rates (flows from employment to unemployment). Additionally allowing for differences in cyclical sensitivity depending on job tenure, the results indicate that workers with a short job tenure are the most influenced by the cycle while workers with a long job tenure experience less pronounced swings.

The remainder of the paper is organized as follows: Section 2 provides a brief overview of the literature, while Sect. 3 describes the data used and the estimation framework. Section 4 documents the estimation results regarding the flows between the labor force states with an emphasis on transitions between jobs. Finally, Sect. 5 concludes.

\section{Related literature}

As Burda and Wyplosz (1994) show, persistent unemployment rates do not imply a low activity on the labor market. Rather, the gross flows are quite high and the level of unemployment is a result of the transition rates between the core labor-market states of employment, unemployment, and nonparticipation. Therefore, an examination of the transition rates provides insights into the heterogeneity of unemployment rates and especially the heterogeneity of cyclical sensitivity. At the aggregate level, there exists an extensive literature on labor-market dynamics (for an overview see Yashiv 2008). Most of these studies find that separations are quite flat over the business cycle, while new hires are more volatile.

Besides the transitions between unemployment and employment, the transitions between different jobs are also of interest since they have some influence on the wage distribution. Fitzenberger and Garloff (2007) find for Germany that job-to-job transitions lead to wage gains for most movers. Nagypál (2008) and Fallick and Fleischmann (2004) find, when using the Current Population Survey (CPS) in the U.S., these transitions to be quite frequent with $2.4 \%$ and $2.6 \%$ per month, respectively. Job-to-job transition intensities in the U.S. are therefore more than twice as high as transitions from employment to unemployment. The findings for the yearly U.S. job-to-job rates differ across various studies. Royalty (1998) finds a transition rate of $16 \%$ for women and $20 \%$ for men with the National Longitudinal Survey of Youths. Blanchard and Diamond (1990) observe a mean rate of $12 \%$ for the years 1975-1985 using the CPS, while Stewart (2002) reports $8.6 \%$ to $13.7 \%$ for the years $1975-2000$. In contrast, Bachmann (2005) observes a monthly job-to-job transition rate of only $0.82 \%$ for West Germany using the IAB employment subsample (IABS). Using the same data, Fitzenberger and Garloff (2007) observe a yearly job-to-job transition rate of $7.72 \%$. This rate is lower than the findings for the U.S. but also higher than the corresponding transition intensity from employment to unemployment.

Moreover, the job-to-job transitions in Bachmann (2005) differ between industries and sexes. Men experience higher job-to-job transitions than women. Similar to Bookmann and Steffes (2008), he finds that transition rates differ between education groups and that younger workers have the highest job-to-job transitions. In addition, Bookmann and Steffes (2008) show, by using linked employer-employee data, that the existence of a works council and investment in further training reduce the job-to-job transition rate.

Fitzenberger and Garloff (2007) as well as Hirsch et al. (2010) find for Germany that job-to-job transition rates are procyclical. The findings of Bachmann $(2005,2007)$ also suggest that separations are quite flat over the cycle, while accessions are procyclical. Gartner et al. (2009) observe a higher volatility of unemployment and the job-finding rate in Germany than in the U.S. between 1977 and 2004. Jung and Kuhn (2009) detect that firings explain $80 \%$ of the unemployment volatility. Furthermore, workers with less than 2 years tenure experience $75 \%$ of all firings. Therefore, workers with a short tenure seem to be decisive for a huge part of volatility in unemployment rates. Their findings suggest that most of these quits are due to a low 
match quality. While job-to-job transitions are important for cyclical behavior, Bachmann (2007) shows that the transitions between employment and nonparticipation are decisive for structural changes between sectors and industries.

The studies covering the U.S. find job-to-job transitions to be procyclical (e.g., Petrongolo and Pissarides 2001). In contrast, the results of Burda and Wyplosz (1994) show that job-to-job flows in France, Germany, and the UK are countercyclical. Besides heterogeneity between worker groups and the correlation between the business cycle and different transition rates, it is of interest which workers are the most or least influenced by the cycle. To address heterogeneity in the cyclical sensitivity across different demographic groups, Kluve et al. (2009) employ a model that allows for heterogeneity in the cyclical dependence of labor-market dynamics by means of cyclical loading factors. In their empirical implementation, they use the retrospective information of the German Socioeconomic Panel (SOEP). Their findings suggest that the re-employment rate, i.e., the transition from unemployment to employment, is the most decisive rate for differences in unemployment. Young workers experience more pronounced swings while women experience less pronounced swings in their re-employment rate.

\section{Data and estimation framework}

The empirical application employs the IAB employment subsample (IABS). It is a $2 \%$ random sample of all employees registered with the German social insurance system between 1 January 1975 and 31 December 2004. The dataset contains daily information on employment and registered unemployment. For our analysis, West and East Germany are examined separately. Furthermore, we restrict our estimation sample to those workers aged 16 to 64 years. The disadvantage of this data is that it does not consider all kinds of employment since it does not cover spells of self-employment, family workers, judges, civil servants, soldiers, conscripts, individuals in community service as an alternative to military service, students enrolled in higher education, and marginally employed before the year 1999. Yet, this is compensated by the fact that the data is process-produced and that it contains a high number of observations. In contrast to surveys, exact dates of a spell and the wages are quite reliable. Unemployment can be measured by spells of benefit reception. However, unemployment without benefit reception cannot be observed. Nevertheless, the large majority of the working population is covered by the data. For instance, in 1995, $79.4 \%$ of all people in paid work in West Germany appear in the data Bender et al. (1999).
Three core labor-market states can be distinguished in the data: employment (E), unemployment (U), and nonparticipation $(\mathrm{N})$. The data does not contain any information on the concrete mode of nonparticipation. However, the only indicator for nonparticipation is leaving the dataset. There is some measurement error because we cannot distinguish those becoming civil servants and those becoming self-employed from those that leave the labor market and we will never observe those never receiving unemployment benefits and never being employed in a regular job (under the requirement of social security contributions). Furthermore, another problem emerges when calculating the stock of nonparticipants. It is not possible to observe if someone dies. The person is counted as nonparticipating until the age of 64. However, this problem affects only the level of nonparticipation which is not important for this study. Every month, people between 16 and 64, who are not working or registered unemployed are counted as not participating. It is assumed that the education level as well as the region (East, West) remains the same in these periods of nonparticipation as it was when they were last observed. If parallel spells occur, we only take the first employment spell into account and the spell of unemployment benefits if no employment spell occurs.

Unemployment spells can only be observed if workers receive unemployment benefits. Otherwise, they are counted as nonparticipants. If someone resigns from a job, he is not eligible for unemployment benefits for up to the first 12 weeks. We therefore counted the first three months after an employment spell as unemployed if unemployment benefit reception or employment occurs after that period.

We construct a monthly dataset out of the spell data. Since the IABS is a daily data base, several states can be observed during one month. We therefore take the longest spell in each month. Because of this approach, short spells of less than 15 days are not covered by the analysis. ${ }^{1}$ Job changes can only be observed by a change in plant number. However, such changes may also be due to restructuring within the firm or if the workers move to a different plant of the same firm.

As a measure for the business cycle, GDP growth is chosen. This data is derived from the federal statistical office Statistisches Bundesamt (2010) and contains GDP growth on the quarterly level.

The empirical strategy is an enhancement of Kluve et al. (2009). In particular, 18 demographic cells are distinguished, defined by sex, three education groups, and three age groups. The group of unskilled workers comprises

\footnotetext{
${ }^{1}$ If two spells of the same length (15 days) are in one month, we always take the first spell as the employment status of the respective month.
} 
those without a high school degree (Abitur) and without a vocational degree. Medium-skilled workers are those with a high school degree or a vocational degree, and highskilled workers, those with a university degree. The age groups are defined as follows: young (16-25), medium-aged (26-49), and old (50-64). Because of the small cell sizes, the group of young and high-skilled is excluded from the analysis. We therefore end up with 16 demographic groups. In addition to this differentiation between demographic groups, we distinguish employed workers by their duration in the employment status, job duration, and duration in the same occupation. We group those with a short duration of up to six months, medium duration between seven and 24 months and long duration with more than 24 months. Furthermore, we distinguish similar duration groups for state dependence in unemployment.

Descriptive statistics for men and women in East and West Germany are displayed in Table 1. The mean unemployment rate of East German women (22\%) is particularly high, but also East German men experience an unemployment rate of almost $19 \%$. In contrast, unemployment rates in West Germany are much lower $(7 \%)$. Remarkably, the education levels are also higher in the East than in the West. Furthermore, the education levels of men and women are quite similar in the East, while there are bigger differences in the West.
The model we adopt assumes that a given transition rate $\pi$ does not only differ in its mean value between the demographic cells but also differs in its cyclical sensitivity between these groups. Cyclical sensitivity is expressed as the deviation of the reaction to aggregate cyclical swings from that of the core group. The core group is defined as medium-aged, medium-skilled men with a medium duration in the respective labor-market state. Therefore, the estimation equation consists of two parts:

$$
\begin{aligned}
\pi_{\text {igmt }}=\alpha & +\sum_{i \neq 5} \beta_{i}+\sum_{j \neq 2} \gamma_{j} \times 1_{j} \sum_{m \neq 6} \mu_{m} \times 1_{m}+ \\
& \tau_{\mathrm{GDP}} \times\left(1+d_{\mathrm{f}} \times 1_{\text {fem }}+d_{\mathrm{u}} \times 1_{\text {unskilled }}+\right. \\
& d_{\mathrm{h}} \times 1_{\text {high-skilled }}+d_{\mathrm{y}} \times 1_{\text {young }}+d_{\mathrm{o}} \times 1_{\text {old }}+ \\
& \left.d_{\mathrm{s}} \times 1_{\text {short }}+d_{\mathrm{l}} \times 1_{\text {long }}\right) \times \Delta \mathrm{GDP}_{t}+\epsilon_{\text {igmt }} .
\end{aligned}
$$

The first part explains the differences in transition rates between the 16 demographic groups $i(i=1, \ldots, 16)$, tenure (state dependence) $j(j=1, \ldots, 3)$, and the month $m(m=1, \ldots, 12)$. The mean transition rate of the core group is captured by $\alpha$. The coefficients $\beta_{i}$ and $\gamma_{j}$ describe the differences in transition rates of workers from that for the core group. Seasonality is captured by $\mu_{m}$ for the different months, where June is the reference category.

The second part of the equation describes the cyclical

\begin{tabular}{|c|c|c|c|c|}
\hline & $\begin{array}{l}\text { West Germany } \\
(1975-2004) \\
\text { Men }\end{array}$ & Women & $\begin{array}{l}\text { East Germany } \\
(1992-2004) \\
\text { Men }\end{array}$ & Women \\
\hline Observations & $167,893,681$ & $140,241,410$ & $24,734,115$ & $24,100,480$ \\
\hline Unemployment rate & 7.18 & 6.58 & 18.88 & 22.05 \\
\hline Young (16-24 yrs) & 23.1 & 24.9 & 25.35 & 25.08 \\
\hline Medium (25-49 yrs) & 55.8 & 56.73 & 58.89 & 60.07 \\
\hline Old (50-64 yrs) & 21.1 & 18.37 & 15.76 & 14.85 \\
\hline Low-skilled & 28.38 & 34.69 & 11.29 & 11.44 \\
\hline Medium-skilled & 63.07 & 60.21 & 77.3 & 79.4 \\
\hline High-skilled & 8.55 & 5.1 & 11.41 & 9.16 \\
\hline Employed & 55.91 & 48.55 & 31.38 & 29.41 \\
\hline Unemployed & 4.33 & 3.42 & 7.3 & 8.32 \\
\hline Nonparticipating & 39.76 & 48.03 & 61.32 & 62.27 \\
\hline \multicolumn{5}{|c|}{ Duration in the economic status } \\
\hline Short $(<6 \mathrm{~m})$ & 11.39 & 11.55 & 11.78 & 10.52 \\
\hline Medium (6-12 m) & 7.83 & 8.47 & 8.27 & 8.12 \\
\hline Medium (13-24 m) & 11.57 & 12.81 & 11.97 & 12.10 \\
\hline Long duration $(>24 \mathrm{~m})$ & 69.22 & 67.18 & 67.98 & 69.26 \\
\hline \multicolumn{5}{|l|}{ Firm tenure } \\
\hline Short $(<6 \mathrm{~m})$ & 14.06 & 15.42 & 21.37 & 18.66 \\
\hline Medium (6-12 m) & 23.64 & 26.58 & 33.27 & 31.44 \\
\hline Long $(>12 \mathrm{~m})$ & 62.30 & 58.00 & 45.35 & 49.90 \\
\hline \multicolumn{5}{|l|}{ Duration in occupation } \\
\hline Short $(<6 \mathrm{~m})$ & 12.89 & 13.73 & 19.11 & 16.47 \\
\hline Medium (6-12 m) & 22.36 & 24.40 & 30.71 & 28.28 \\
\hline Long $(>12 \mathrm{~m})$ & 64.75 & 61.87 & 50.18 & 55.25 \\
\hline
\end{tabular}
sensitivity of the transition rate. First, we take GDP growth
Table 1 Descriptive statistics of the two samples
Note: Except for the number of observations, the number represent percentages. 
as an indicator for the business cycle. Its influence in the transition rate is captured by its coefficient $\tau_{\mathrm{GDP}}$. For five (seven) groups, loading factors allow their cyclical behavior to deviate from the average cycle: female (loading factor $\left.d_{\mathrm{f}}\right)$, unskilled $\left(d_{\mathrm{u}}\right)$, high-skilled $\left(d_{\mathrm{h}}\right)$, young $\left(d_{\mathrm{y}}\right)$, and old $\left(d_{0}\right)$ workers. In a second specification, two additional loading factors are added: short tenure (state dependence) $\left(d_{\mathrm{s}}\right)$ and long tenure (state dependence) $\left(d_{1}\right)$. The loading factors amplify or dampen the cyclical swings in transition intensity. A positive value would indicate that this group experiences the cyclical influence in a more pronounced way, while a negative value indicates that for this group the cyclical swings are less pronounced. A value of -1 would even imply that this group is detached from the cycle. The error term is represented by $\epsilon_{\text {igmt }}$.

Indeed, the above-used measure of the business cycle is quite naively chosen by the quarterly GDP growth rate. This procedure can be criticized because different measures could be more appropriate than GDP growth. Furthermore, it is often stated and argued that the labor market reacts with some delay to the business cycle. Therefore, it could be necessary to implement different alternative measures and a lag structure. However, this procedure still assumes that the influence of upswings and downswings on the transition rate is symmetric (the decrease/increase in an upswing is of the same size as the increase/decrease in a comparable downswing). Furthermore, it is assumed that the correlation stays the same over the whole period. Therefore, we implement an even more flexible structure to explore the issue of cyclical sensitivity more deeply. Year dummies for the period 1975-1992 for West Germany, and 1993-2004 for both parts of the country are included in the model. We treat the aggregate cycle as an unobservable, and estimate its impact to be $\tau_{t}(t=1, \ldots, 30)$ for the typical worker. This period-specific coefficient is interacted with some set of loading factors to allow for heterogeneity in cyclical behavior. This change implies that there is a nonlinear relationship between economic activity on the one hand and cyclical reactions on the other:

$$
\begin{aligned}
\pi_{\text {igmt }}= & \alpha+\sum_{i \neq 5} \beta_{i}+\sum_{i \neq 2} \gamma_{j} \times 1_{j} \sum_{m \neq 6} \mu_{m} \times 1_{m}+ \\
& \sum_{t \neq 19} \tau_{t} \times\left(1+d_{\mathrm{f}} \times 1_{\text {fem }}+d_{\mathrm{u}} \cdot 1_{\text {unskilled }}+\right. \\
& d_{\mathrm{h}} \times 1_{\text {high-skilled }}+d_{\mathrm{y}} \cdot 1_{\text {young }}+d_{\mathrm{o}} \times 1_{\text {old }}+ \\
& \left.d_{\mathrm{s}} \times 1_{\text {short }}+d_{1} \times 1_{\text {long }}\right) \times 1_{t}+\epsilon_{\text {igmt }} .
\end{aligned}
$$

All equations are estimated for West and East Germany separately with nonlinear least squares. The observations (demographic cells) are weighted with the number of persons in the origin status. Because of the short time period of only 13 years in East Germany, it has to be kept in mind that we can only observe a part of a business cycle.

\section{Results}

\subsection{Aggregate monthly flows}

Figure 1 documents the typical transition intensities between labor-market states in our sample. The mean monthly flows are measured as the share of the stock of workers in the previous state for all transitions. In West Germany, some $6.4 \%$ of all unemployed workers return to employment per month while another $4.4 \%$ leave the labor market. The transition rates out of unemployment $(4.7 \%$ and 2.8\%) are lower in the East, while the job-loss rate (from employment to unemployment) is higher in the East $(1.6 \%)$ than in the West $(0.6 \%)$. Overall, the pool of unemployed workers is quite persistent, with some $89.3 \%$ in the West and some $92.5 \%$ in the East retaining their status in a typical month. This observation applies even more intensely to the state of nonparticipation.

In this paper, we focus on job-to-job transitions which are compared to movements into and out of the state of employment. The monthly rate of job-to-job transitions of $1.1 \%$ (West) and $1.2 \%$ (East) are in the same range for West Germany as those found by Bachmann (2005). These transition rates are the largest in West and East Germany. However, these job-to-job transitions are lower than those found for the U.S. Most importantly, job-to-job transitions tend to be more frequent than either transition to unemployment or to nonparticipation. Consequently, a comprehensive analysis of German labor-market dynamics needs to take them into account. In the following subsections, we will look more closely at the anatomy of job-to-job flows with respect to age, gender and skills, job tenure, and over the economic cycle.

\subsection{Heterogeneity of job-to-job transitions}

The previous subsection has documented the importance of job-to-job transitions in explaining the overall turbulence of the German labor market. Here, we take a closer look at the differences between worker groups in their transition probabilities. Table 2 presents the estimated coefficients $\beta_{i}$ in Eq. (2) that give some insights into the differences between the groups. All coefficients show the difference to the core group of male, medium-skilled, medium-aged workers. The coefficients estimated for West Germany indicate that young male workers and young medium-skilled female workers have significantly higher transition rates than the core group. In contrast, old workers less often change from one job to another. The transition rates of medium-aged women without a university degree are lower than those of their male counterparts. The estimated coefficient for the demographic groups in East Germany are presented in Table 3. Young and low-skilled workers as well as old workers of at least 
Fig. 1 Average monthly worker flows, IABS. Notes: The figures are in percent. The figures corresponding to the grey arrows indicate the share of workers remaining in the respective labor-market state; for employment, the number in parentheses also document the frequency of job-to-job flows, i.e., of the $98.11 \%$ of workers in the West who stay employed in a typical month, $96.98 \%$ remain in their old job, while $1.13 \%$ change their jobs

Table 2 Job-to-job transitions in West Germany: deviation from the core group

\begin{tabular}{|c|c|c|c|}
\hline \multicolumn{4}{|l|}{ Men } \\
\hline $\begin{array}{l}\text { Young } \\
\text { (16-24) }\end{array}$ & $\begin{array}{c}\text { Unskilled } \\
0.159 \\
(3.69)\end{array}$ & $\begin{array}{c}\text { Medium-skilled } \\
0.362 \\
(10.83)\end{array}$ & $\begin{array}{c}\text { High-skilled } \\
- \\
-\end{array}$ \\
\hline $\begin{array}{l}\text { Medium } \\
(25-49)\end{array}$ & $\begin{array}{r}0.046 \\
(1.33)\end{array}$ & - & $\begin{array}{c}0.103 \\
(2.22)\end{array}$ \\
\hline $\begin{array}{l}\text { Old } \\
(50-64)\end{array}$ & $\begin{array}{l}-0.406 \\
(-8.44)\end{array}$ & $\begin{array}{l}-0.303 \\
(-9.39)\end{array}$ & $\begin{array}{c}-0.091 \\
(-1.01)\end{array}$ \\
\hline \multicolumn{4}{|l|}{ Women } \\
\hline $\begin{array}{l}\text { Young } \\
\text { (16-24) }\end{array}$ & $\begin{array}{c}\text { Unskilled } \\
-0.017 \\
(-0.36)\end{array}$ & $\begin{array}{c}\text { Medium-skilled } \\
0.513 \\
(15.55)\end{array}$ & $\begin{array}{c}\text { High-skilled } \\
- \\
-\end{array}$ \\
\hline $\begin{array}{l}\text { Medium } \\
(25-49)\end{array}$ & $\begin{array}{l}-0.178 \\
(-4.52)\end{array}$ & $\begin{array}{l}-0.102 \\
(-4.14)\end{array}$ & $\begin{array}{c}0.034 \\
(0.49)\end{array}$ \\
\hline $\begin{array}{l}\text { Old } \\
(50-64)\end{array}$ & $\begin{array}{c}-0.411 \\
(-8.76)\end{array}$ & $\begin{array}{l}-0.381 \\
(-9.56)\end{array}$ & $\begin{array}{l}-0.104 \\
(-0.53)\end{array}$ \\
\hline
\end{tabular}

Note: Numbers in parentheses are $t$-values.

Table 3 Job-to-job transitions in East Germany: deviation from the core group

\begin{tabular}{lccc}
\hline Men & & & \\
& Unskilled & Medium-skilled & High-skilled \\
Young & -0.432 & 0.271 & - \\
$(16-24)$ & $(-6.78)$ & $(4.99)$ & - \\
Medium & 0.199 & - & -0.039 \\
$(25-49)$ & $(2.26)$ & - & $(-0.64)$ \\
Old & -0.114 & -0.352 & -0.322 \\
$(50-64)$ & $(-0.71)$ & $(-8.41)$ & $(-4.15)$ \\
& & & \\
Women & & & \\
Young & Unskilled & Medium-skilled & High-skilled \\
$(16-24)$ & $(-0.332$ & 0.234 & - \\
Medium & -0.005 & $(3.89)$ & - \\
$(25-49)$ & $(-0.06)$ & -0.258 & -0.138 \\
Old & -0.070 & $(-7.92)$ & $(-2.16)$ \\
$(50-64)$ & $(-0.53)$ & $(-9.79)$ & -0.238 \\
\hline
\end{tabular}

Note: Numbers in parentheses are $t$-values. medium skill level have the smallest job-to-job transition rates in the East. The job-to-job transition rates do not differ significantly between men and women for most groups in both parts of the country.

\subsection{Cyclical behavior of job-to-job transitions}

This section compares the results of estimating Eqs. (1) and (2) between the various transition intensities beginning with a focus on the estimated cyclical coefficients $\tau_{\mathrm{GDP}}$. Table 4 shows the estimated coefficients $\tau_{\mathrm{GDP}}$ in Eq. (1) for the job-to-job transition, job-loss, and job-finding rates in West and East Germany separately. (The full estimation results for the job-to-job flows are presented in the Appendix.) The coefficients are those of Eq. (1) and therefore reflect the cyclical sensitivity for the baseline group (medium-skilled, middle-aged men). The estimated coefficient is negative for the job-loss rate $\tau_{\mathrm{GDP}}^{\mathrm{EU}}$ in West Germany and therefore indicates that the job-loss rate is countercyclical. However, the estimated coefficient for East Germany is positive. This finding is in contrast to the existing literature and theoretical considerations and can be due to the short observation period for East Germany. However, the estimated coefficient for the re-employment rate $\tau_{\mathrm{GDP}}^{\mathrm{UE}}$ is positive and significant for both parts of Germany. Thus,

Table 4 Cyclical sensitivity of transitions: estimation results

\begin{tabular}{lrr}
\hline$\tau_{\mathrm{GDP}}^{\mathrm{EE}}$ & \multicolumn{1}{c}{$\tau_{\mathrm{GDP}}^{\mathrm{EU}}$} & \multicolumn{1}{c}{$\tau_{\mathrm{GDP}}^{\mathrm{UE}}$} \\
\hline West Germany & & \\
0.006 & -0.047 & 0.469 \\
$(0.81)$ & $(-12.95)$ & $(20.84)$ \\
& & \\
East Germany & & \\
-0.018 & 0.054 & 0.373 \\
$(-1.26)$ & $(3.12)$ & $(11.95)$ \\
\hline
\end{tabular}

Notes: Estimated coefficients of Eq. (1). The estimated coefficients are those for the core group of male, medium-aged, medium-skilled workers. Asymptotic $t$-values are in parentheses. 
the re-employment rate seems to be procyclical which is in line with the literature (e.g., Bachmann 2005).

The estimated coefficients for the GDP growth in the analysis of job-to-job transitions are insignificant for West and East Germany. This finding is in contrast with findings for the U.S. (e.g., Petrongolo and Pissarides 2001), which indicates that job-to-job transitions are procyclical. However, this model only captures the influence of contemporaneous GDP growth and assumes symmetric and linear influence of GDP growth on the transition rates. Therefore, we apply the second model described above which is more flexible in modeling cyclical behavior.

The estimated coefficients for the time dummies (1993 is the reference year) are displayed in Figs. 2 and 3 for the job-loss rate and the job-finding rate, respectively. The graphical presentation of the estimated coefficients supports the findings of estimating Eq. (1) that the job-loss rate in West Germany is countercyclical while the job-finding rate is procyclical. However, the correlation coefficients of the estimated time structure and the GDP growth are relatively small $(-0.14$ and 0.10 , respectively). The figure for East Germany clarifies that the observation period is quite short

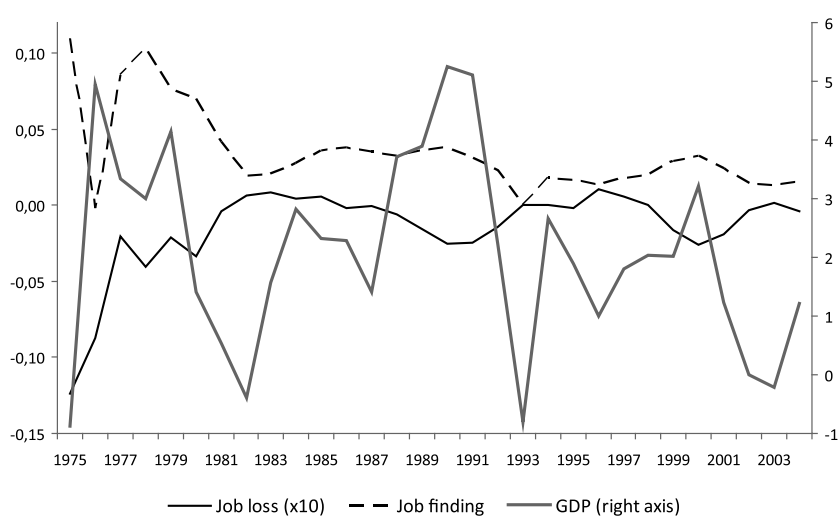

Fig. 2 Cyclical sensitivity of job finding and job loss - West Germany

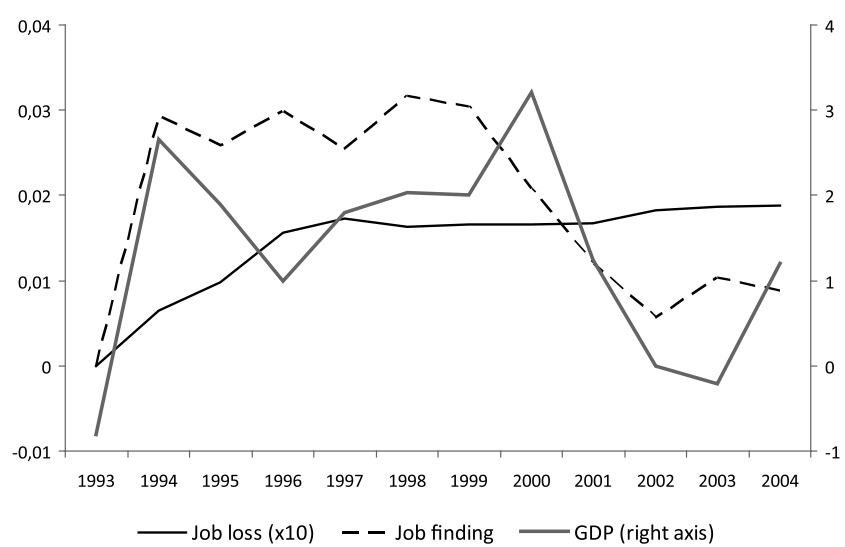

Fig. 3 Cyclical sensitivity of job finding and job loss - East Germany and captures a long period of medium GDP growth and only three years of low GDP growth. Therefore, changes in the different rates (especially the job-loss rate) seem to be mostly driven by factors other than cyclical changes. However, the job-finding rate seems to be procyclical as the previous result also indicated.

The cyclical sensitivity of the job-to-job rates is displayed in Fig. 4. The estimated coefficients for the year dummies show that the job-to-job transition rate is procyclical. However, the decrease in the job-to-job transitions between 2000 and 2002 is less pronounced than the decrease in GDP growth. The correlation of the coefficients and the GDP growth is only -0.04 . However, when examining only the time period until 2001, it is 0.44 . Furthermore, transition rates in 2003 are again rising while GDP growth is still decreasing. These findings suggest that the job-to-job rate is procyclical but that this relationship is offset in the most recent years of the data. However, to determine whether this effect is long-lasting, additional observation periods are necessary.

The main interest of this study is to investigate whether different demographic groups are more or less influenced by the economic cycle than the core group of male, mediumskilled, medium-aged men. The loading factors in the applied model give some insights into the differences in cyclical sensitivity. The estimated loading factors for applying the two models to the job-to job rate in East and West Germany are displayed in Table 5. (Full estimation results are presented in the Appendix.) In West Germany, high-skilled workers experience less pronounced swings than the core group. This finding suggests that the job-to-job transition rate is not raised as much as that of the core group in an economic upswing. However, the job-to-job transitions decrease less in economic downturns. The same is true for old workers that are also less sensitive to the cycle than the core group.

The estimated coefficients for the demographic groups show that young workers are more likely to change from one

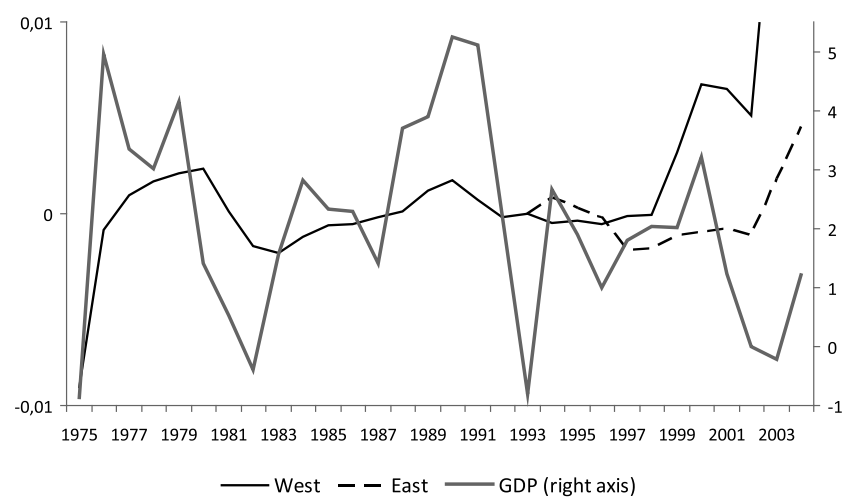

Fig. 4 Cyclical sensitivity of job-to-job transitions 
Table 5 Job-to-job transition rates: excess cyclical sensitivity

Table 6 Transition rates between employment and unemployment: excess cyclical sensitivity

\begin{tabular}{lcclccc}
\hline Women & Unskilled & $\begin{array}{l}\text { High- } \\
\text { skilled }\end{array}$ & Young & Old & Short & Long \\
\hline $\begin{array}{c}\text { West Germany } \\
0.197\end{array}$ & 0.358 & -0.455 & -0.162 & -0.336 & - & - \\
$(6.92)$ & $(10.43)$ & $(-9.18)$ & $(-4.57)$ & $(-11.35)$ & - & - \\
0.249 & 0.344 & -0.629 & -1.311 & -0.249 & 6.165 & -0.442 \\
$(8.29)$ & $(9.33)$ & $(-12.74)$ & $(-26.11)$ & $(-8.13)$ & $(25.33)$ & $(-18.38)$ \\
& & & & & & \\
$\begin{array}{c}\text { East Germany } \\
0.399\end{array}$ & 0.106 & 0.033 & -0.082 & -0.017 & - & - \\
$(3.10)$ & $(0.55)$ & $(0.19)$ & $(-0.49)$ & $(-0.14)$ & - & - \\
\hline
\end{tabular}

Notes: The models were estimated via nonlinear least squares. Asymptotic $t$-values are in parentheses.

\begin{tabular}{|c|c|c|c|c|c|c|}
\hline Women & Unskilled & $\begin{array}{l}\text { High- } \\
\text { skilled }\end{array}$ & Young & Old & Short & Long \\
\hline \multicolumn{7}{|c|}{ West Germany } \\
\hline \multicolumn{7}{|c|}{ Transitions from employment to unemployment } \\
\hline-0.055 & 0.712 & -0.465 & -0.559 & -1.113 & - & - \\
\hline$(-0.54)$ & $(3.80)$ & $(-2.89)$ & $(-4.35)$ & $(-8.60)$ & - & - \\
\hline-0.051 & 0.630 & -0.406 & -0.493 & -0.978 & -0.214 & -0.162 \\
\hline$(-0.56)$ & $(3.84)$ & $(-2.79)$ & $(-4.18)$ & $(-7.68)$ & $(-1.82)$ & $(-1.33)$ \\
\hline \multicolumn{7}{|c|}{ Transitions from unemployment to employment } \\
\hline-0.785 & 0.123 & -0.250 & 0.159 & -0.606 & - & - \\
\hline$(-15.80)$ & $(2.08)$ & $(-1.58)$ & $(2.00)$ & $(-10.91)$ & - & - \\
\hline-1.248 & 0.243 & -0.426 & 0.021 & -0.800 & 1.121 & 0.225 \\
\hline$(-10.42)$ & $(2.42)$ & $(-1.70)$ & $(0.17)$ & $(-8.17)$ & $(6.12)$ & $(1.65)$ \\
\hline \multicolumn{7}{|c|}{ East Germany } \\
\hline \multicolumn{7}{|c|}{ Transitions from employment to unemployment } \\
\hline-0.502 & -0.201 & -0.209 & -0.076 & -0.186 & - & - \\
\hline$(-12.86)$ & $(-2.24)$ & $(-2.56)$ & $(-1.06)$ & $(-3.40)$ & - & - \\
\hline-0.407 & -0.217 & -0.156 & -0.104 & -0.140 & -0.079 & -0.718 \\
\hline$(-13.27)$ & $(-3.32)$ & $(-2.62)$ & $(-1.94)$ & $(-3.40)$ & $(-1.55)$ & $(-19.58)$ \\
\hline \multicolumn{7}{|c|}{ Transitions from unemployment to employment } \\
\hline-0.486 & -0.194 & -0.006 & 0.151 & -0.768 & - & - \\
\hline$(-6.45)$ & $(-1.37)$ & $(-0.02)$ & $(0.88)$ & $(-8.33)$ & - & - \\
\hline-0.444 & -0.170 & 0.008 & 0.186 & -0.671 & -0.310 & -0.080 \\
\hline$(-6.64)$ & $(-1.42)$ & $(0.04)$ & $(1.26)$ & $(-8.03)$ & $(-3.86)$ & $(-0.77)$ \\
\hline
\end{tabular}

Notes: The models were estimated via nonlinear least squares. Asymptotic $t$-values are in parentheses. job to another than other age groups. Additionally, the estimated loading factor suggests that they are slightly less sensitive to cyclical influences than the core group. Therefore, young workers always have high job-to-job transition rates which are only moderately cyclical. This finding can be due to the vocational training system in Germany. In contrast, women do indeed experience relatively pronounced swings compared to their male counterparts. There is a similar finding for unskilled workers. Their job-to-job rates are raised moderately above average in an economic downswing and lowered moderately more than for the core group worker in an economic upswing. All of these estimated coefficients are relatively small in their absolute value which indicates that the deviations from the overall cyclical behavior are moder- ate and that none of the groups is completely detached from the cycle.

In East Germany, there are no significant differences between the demographic groups except for women who experience a more pronounced development in job-to-job transitions than the core group. The fact that the estimated coefficients are mainly insignificant may be due to the short observation period for East Germany.

In addition to the difference in cyclical behavior of the demographic groups, we investigate whether the duration in the respective occupation has an influence on the cyclical dependency. The results suggest that workers with a short duration in their occupation are more influenced by cyclical effects. In contrast, those with a long duration in the occu- 
pation are less sensitive compared to those with a medium duration (6-24 months). In combination with the estimated coefficients for the duration in occupation, it can be summarized that the probability of job changes is the highest and the most influenced by cyclical swings at the beginning of a career in an occupation. This finding is in line with the results in Jung and Kuhn (2009), where high job-to-job transition rates at the beginning of an employment spell are observed, which is due to low job match quality. These findings are robust to replacing the duration in occupation with the duration in a firm. ${ }^{2}$

Finally, Table 6 presents the loading factors for the jobfinding and job-loss rate. It can be seen that women are less sensitive to the cycle in terms of both, the job-finding and job-loss rates. This is in contrast to their sensitivity in job-tojob transitions. The results indicate that there is only moderate cyclical influence on women's transition between employment and unemployment while there is an even more pronounced influence on their job-to-job transition rate. By contrast, high-skilled workers and old workers experience less pronounced swings in all three transition rates compared to the core group. Unskilled workers in West Germany experience more pronounced swings than the core group in all three transition rates. This group is the most affected by cyclical changes. Regarding the duration in unemployment those with a short unemployment spell are the most influenced by the cycle in their job-finding rate.

\section{Concluding remarks}

This paper analyzes the German labor market by examining its dynamics and their cyclical sensitivity. The main focus of this analysis is the heterogeneity in the dynamics of jobto-job flows. We do not only allow for differences between demographic groups in the size of the transition rates but also in their cyclical sensitivity. Furthermore, job tenure and experience in an occupation is taken into account. Using the IAB employment subsample for the years 1975 to 2004 for West Germany and 1993 to 2004 for East Germany, 18 demographic groups and three job-duration groups are distinguished. Job-to-job transitions are large compared to other transitions and therefore form a substantial part of labor-market dynamics. However, compared to U.S. findings, these rates are somewhat smaller.

Using GDP growth and, in a nonlinear model, a more flexible specification of year dummies, cyclical dependence is estimated. Loading factors account for the deviation in the cyclical sensitivity from that of the core group. The job-tojob rate is found to be acyclical using GDP growth as the

\footnotetext{
${ }^{2}$ Regression results are available from the author upon request.
}

cyclical indicator. However, estimating year dummies suggest that the rate is procyclical whereas the most recent years are somewhat detached from the cycle.

These findings supplement those of Kluve et al. (2009) using the SOEP for job-loss and re-employment rates. They also confirm the findings of earlier studies (Bachmann 2005; Nagypál 2008) that re-employment rate and job-to-job transition rates are large and procyclical. However, our findings suggest that young workers, old workers, and high-skilled workers are less sensitive to the cycle than the core group, while the job-to-job transition rates of unskilled and female workers are strongly procyclical. Thus, the modified search and matching models of Hall (2005) and Shimer (2005) are more relevant for unskilled workers and women, searching actively for a new job while they are employed, than for old workers. Women and unskilled workers are therefore more likely to realize low-quality matches than other worker groups.

Besides the effect that workers with a short job tenure are more likely to have job-to-job transitions, our results indicate that those workers are even more influenced by the cycle than workers with longer tenure.

\section{Executive summary}

Scarce empirical evidence exists for Germany regarding the cyclical aspects of worker reallocation. Furthermore, it is assumed that the cyclical influence on transition rates is the same for all demographic groups. However, one can expect that each subgroup is differentially influenced by the same cycle.

This paper analyzes the German labor market by examining its dynamics and their cyclical sensitivity. The main focus of this analysis is the heterogeneity in the dynamics of job-to-job flows. We do not only allow for differences between demographic groups in the size of the transition rates but also in their cyclical sensitivity. Furthermore, job tenure and experience in an occupation is taken into account. Using the IAB employment subsample for the years 1975 to 2004 for West Germany and 1993 to 2004 for East Germany, 18 demographic groups and three job-duration groups are distinguished. The demographic groups are defined by age, gender, and skills. Job-to-job transitions are found to be the largest flows in the German labor market and therefore they form a substantial part of labor-market dynamics. However, compared to U.S. findings, these rates are somewhat smaller.

The empirical framework employed here allows demographic groups to vary in their cyclical sensitivity. Using GDP growth and, in a nonlinear model, a more flexible specification of year dummies, cyclical dependence is estimated. Loading factors account for the deviation in 
the cyclical sensitivity from that of the core group. The job-to-job rate is found to be acyclical using GDP growth as the cyclical indicator. However, estimating year dummies suggest that the rate is procyclical whereas the most recent years are somewhat detached from the cycle.

These findings supplement findings for job-loss and re-employment rates. They also confirm the findings of earlier studies that re-employment rate and job-to-job transition rates are large and procyclical. However, our findings suggest that young workers, old workers, and high-skilled workers are less sensitive to the cycle than the core group, while the job-to-job transition rates of unskilled and female workers are strongly procyclical. Thus, the search and matching models are more relevant for unskilled workers and women, searching actively for a new job while they are employed, than for old workers. Women and unskilled workers are therefore more likely to realize low-quality matches than other worker groups.

Besides the effect that workers with short job tenure are more likely to have job-to-job transitions, our results indicate that those workers are even more influenced by the cycle than workers with longer tenure.

\section{Kurzfassung}

Die konjunkturellen Einflüsse auf die Dynamik am Arbeitsmarkt sind ein breit untersuchtes Feld der Literatur. Allerdings ist die empirische Evidenz für Deutschland noch sehr gering. Des Weiteren wird in der bestehenden Literatur meistens angenommen, dass der konjunkturelle Einfluss auf Übergangsraten für alle Gruppen identisch ist. Allerdings lässt sich vermuten, dass konjunkturelle Einflüsse unterschiedlich stark auf verschiedene Arbeitnehmergruppen einwirken.

Diese Studie untersucht die Dynamik des deutschen Arbeitsmarktes und deren konjunkturelle Abhängigkeit. Das Hauptaugenmerk der Analyse liegt auf direkten Übergängen zwischen zwei Beschäftigungsverhältnissen, den sogenannten Job-to-Job-Flüssen. Dabei wird die Heterogenität in diesen Flüssen untersucht. Es wird nicht nur angenommen, dass es Unterschiede in der Größe der Flüsse gibt, sondern auch in ihrer Volatilität. Dabei wird sowohl die Betriebszugehörigkeit als auch die Arbeitsmarkterfahrung der Beschäftigten berücksichtigt. Die Analyse basiert auf der IAB-Beschäftigtenstichprobe und umfasst die Jahre
1975 bis 2004 für Westdeutschland und 1993 bis 2004 für Ostdeutschland. Dabei werden 18 demografische Gruppen nach Geschlecht, Alter und Ausbildung sowie drei Gruppen nach Betriebszugehörigkeit unterschieden. Job-to-JobFlüsse sind die größten Flüsse in Deutschland und daher sehr wichtig für die Arbeitsmarktdynamik. Verglichen mit Ergebnissen für die USA ist diese Transitionsrate aber vergleichsweise gering.

In der empirischen Modellierung können sich demografischen Gruppen nicht nur in der Größe der Flüsse, sondern vor allem auch in ihrer zyklischen Sensitivität unterscheiden. Sowohl das BIP-Wachstum als auch Jahresdummies werden in einem flexibleren nichtlinearen Modell als Indikatoren für den Konjunkturzyklus herangezogen. Sogenannte Ladefaktoren greifen die Unterschiede in der Betroffenheit vom Konjunkturzyklus, verglichen mit der Kerngruppe, ab.

Die Ergebnisse zeigen für Westdeutschland, dass Jobto-Job-Übergänge prozyklisch sind, wobei die vergangenen Jahre von konjunkturellen Einflüssen weniger betroffen erscheinen.

Weiterhin sind die Ergebnisse im Einklang mit der bestehenden Literatur, die feststellt, dass sowohl Transitionen von Arbeitslosigkeit in Erwerbstätigkeit als auch Job-to-Job-Übergänge groß und prozyklisch sind. Darüber hinaus zeigen die Ergebnisse der Studie aber auch, dass die Übergangsraten hochqualifizierter, älterer oder jüngerer Arbeitnehmer weniger volatil sind als die der Kerngruppe mittelqualifizierter Männer mittleren Alters. Im Gegensatz dazu sind die Transitionen von Frauen und Geringqualifizierten volatiler als die anderer Gruppen. Demnach scheinen die Search-and-Matching-Modelle, während einer Beschäftigung nach einem besseren „Match“ zu suchen, vor allem auf Frauen und Geringqualifizierte und weniger auf ältere Arbeitnehmer zuzutreffen. Weibliche und geringqualifizierte Arbeitnehmer scheinen demnach häufiger Beschäftigungsverhältnisse mit einer schlechten „Match“Qualität als andere Arbeitnehmergruppen aufzunehmen.

Während Arbeitnehmer mit einer geringen Betriebszugehörigkeit häufiger direkt in einen anderen Job wechseln, sind die Übergangsraten auch stärker durch konjunkturelle Einflüsse beeinflusst.

Acknowledgements I am grateful to Christoph M. Schmidt, Alfredo Paloyo, the editor, Claus Schnabel, and two anonymous referees for very helpful suggestions and comments. I gratefully acknowledge the support of the Collaborative Research Centre SFB 475 (DFG) and of the Leibniz Association. 


\section{Appendix}

Table 7 Job-to-job transitions in West Germany: results for Eq. (2)

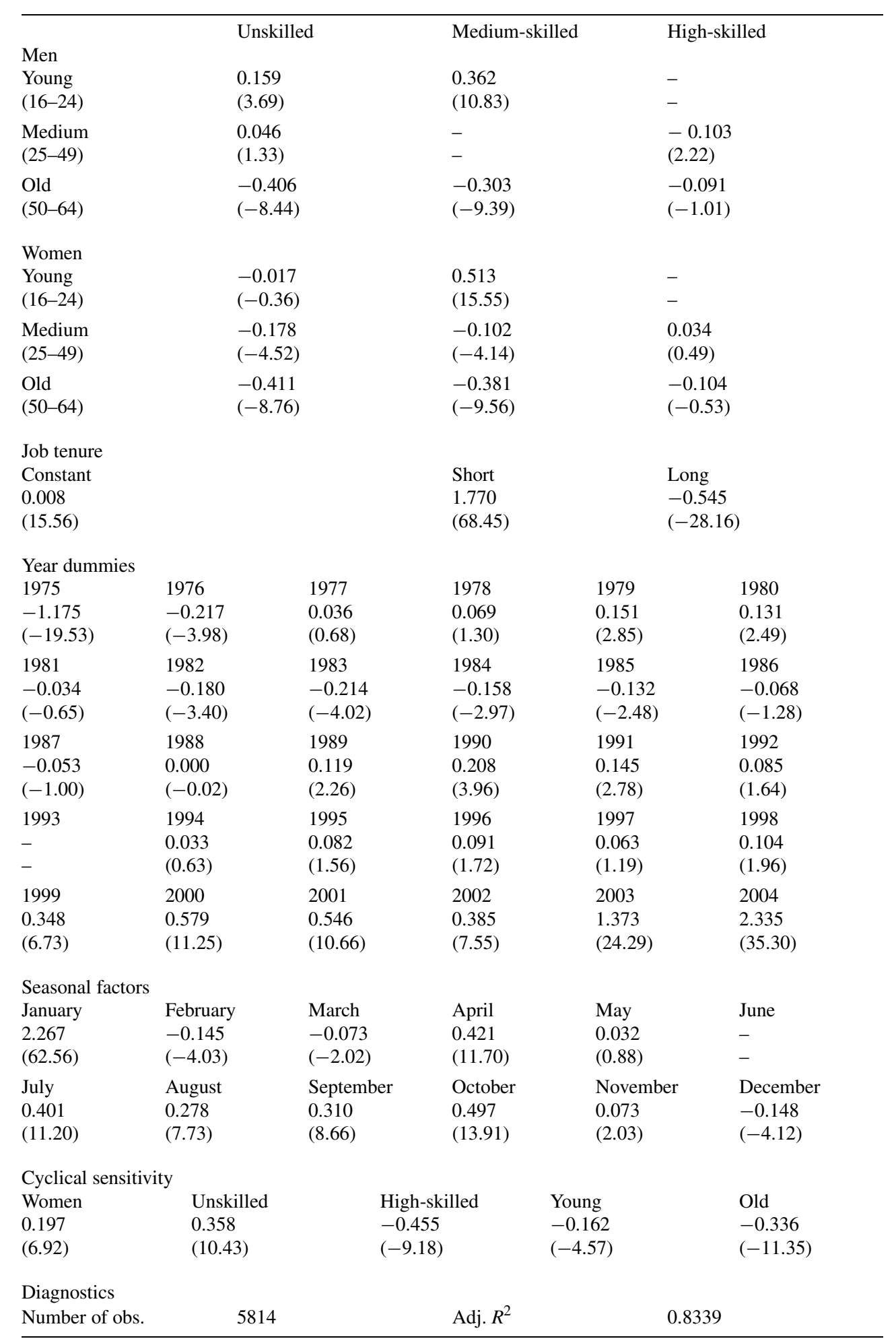

Notes: The model was estimated via nonlinear least squares. Asymptotic $t$-values are in parentheses. 
Table 8 Job-to-job transitions in East Germany: results for Eq. (2)

\begin{tabular}{ll}
\hline Men & Unskilled \\
Young & -0.432 \\
$(16-24)$ & $(-6.78)$ \\
Medium & 0.199 \\
$(25-49)$ & $(2.26)$ \\
Old & -0.114 \\
(50-64) & $(-0.71)$ \\
& \\
Women & \\
Young & -0.332 \\
$(16-24)$ & $(-4.25)$ \\
Medium & -0.005 \\
$(25-49)$ & $(-0.06)$ \\
Old & -0.070 \\
(50-64) & $(-0.53)$
\end{tabular}

Job tenure

Constant

0.012

(24.54)

Year dummies

$\begin{array}{ll}1993 & 1994 \\ - & 0.040\end{array}$

$\begin{array}{ll}- & 0.040 \\ - & (0.94)\end{array}$

1999

$-0.258$

2000

$(-5.41)$

$-0.242$

$(-5.13)$

Seasonal factors

$\begin{array}{ll}\text { January } & \text { February } \\ 3.682 & -0.118 \\ (72.92) & (-2.32) \\ \text { July } & \text { August } \\ 0.348 & 0.204 \\ (6.87) & (4.02)\end{array}$

Cyclical sensitivity

$\begin{array}{ll}\text { Women } & \text { Unskilled } \\ 0.399 & 0.106 \\ (3.10) & (0.55)\end{array}$

Diagnostics

Number of obs. 5814
Medium-skilled

0.271

(4.99)

$-$

$-$

$-0.352$

$(-8.41)$

0.234

(3.89)

$-0.258$

$(-7.92)$

$-0.447$

(-9.79)

Short

1.034

(30.10)

1995

0.042

$(-0.98)$

2001

$-0.219$

(-4.68)

March
-0.041
$(-0.81)$
September
0.297
$(5.85)$

April

0.286

(5.60)

October

0.257

(5.08)

1996
-0.108
$(-2.44)$
2002
-0.267
$(-5.47)$

1997

$-0.329$

(-6.55)

2003

0.067

(1.50)

Long
-0.428
$(-16.14)$

Long
-0.428
$(-16.14)$

Long
-0.428
$(-16.14)$

$(-2.16)$

$-0.238$

$(-2.10)$

$-0.039$

$(-0.64)$

$-0.322$

$-$

$-0.138$$$
(-2.10)
$$

1998
-0.328
$(-6.50)$
2004
-0.391
$(7.21)$

Notes: The model was estimated via nonlinear least squares. Asymptotic $t$-values are in parentheses.

\section{References}

Bachmann, R.: Labour market dynamics in Germany: hirings, separations, and job-to-job transitions over the business cycle. SFB 649 Discussion Paper No. 2005-45. Humboldt-Universität zu Berlin (2005)

Bachmann, R.: A dynamic approach to Germany's unemployment problem. Dissertation, Humboldt University Berlin (2007)

Bender, S., Haas, A., Klose, C.: Die IAB-Beschäftigtenstichprobe 1975-1995. ZA-Information 45, 104-115 (1999)

Blanchard, O., Diamond, P.: The cyclical behavior of gross flows of workers in the US. Brookings Pap. Eco. Ac. 2, 81-155 (1990)
Bookmann, B., Steffes, S.:. Workers, firms, or institutions: what determines job duration for male employees in Germany? Discussion Paper No. 08-116. ZEW, Mannheim (2008)

Burda, M., Wyplosz, C.: Gross worker and job flows in Europe. Eur. Econ. Rev. 38(6), 1287-1315 (1994)

Fallick, B., Fleischmann, C.A.: Employer-to-employer flows in the U.S. labor market: the complete picture of gross worker flows. Finance and Economics Discussion Series No. 2004-34. Board of Governors of the Federal Reserve System (U.S.), Washington D.C. (2004)

Fitzenberger, B., Garloff, A.: Labor market transitions and the wage structure in Germany. Jahrb. Natl. Stat. 227(2), 115-152 (2007) 
Gartner, H., Merkl, C., Rothe, T.: They are even larger! More (on) puzzling labor market volatilities. Discussion Paper No. 4403. IZA, Bonn (2009)

Hall, R.E.: Employment fluctuations with equilibrium wage stickiness. Am. Econ. Rev. 95(1), 50-65 (2005)

Hirsch, B., Schank, T., Schnabel, C.: Differences in labor supply to monopsonistic firms and the gender pay gap: an empirical analysis using linked employer-employee data from Germany. J. Labor Econ. 28(2), 291-330 (2010)

Jung, P., Kuhn, M.: Explaining cross-country labor market cyclicality: U.S. vs. Germany. mimeo. University of Mannheim (2009)

Kluve, J., Schaffner, S., Schmidt, C.: Labor force status dynamics in the German labor market: individual heterogeneity and cyclical sensitivity. Ruhr Economic Paper No. 139. RWI Essen (2009)

Nagypál, E.: Worker reallocation over the business cycle: the importance of employer-to-employer transitions. mimeo. http://faculty. wcas.northwestern.edu/ een461/JJempirical_2008_0207.pdf. Northwestern University (2008)

Petrongolo, B., Pissarides, C.A.: Looking into the black box: a survey of the matching function. J. Econ. Lit. 39(2), 390-431 (2001)

Royalty, A.B.: Job-to-job and job-to-nonemployment turnover by gender and education level. J. Labor Econ. 16(2), 392-443 (1998)
Schmidt, C.: The heterogeneity and cyclical sensitivity of unemployment: an exploration of German labor market flows. Ifo-Studien 46, 73-98 (2000)

Shimer, R.: The cyclicality of hires, separations, and job-to-job transitions. Fed. Reserv. Bank St. Louis Rev. 87(4), 493-507 (2005)

Statistisches Bundesamt: Volkswirtschaftliche Gesamtrechnungen Bruttoinlandsprodukt ab 1970. Vierteljahres- und Jahresergebnisse. Wiesbaden (2010)

Stewart, J.: Recent trends in job stability and job security: evidence from the march CPS. Working Paper No. 356. BLS, Washington D.C. (2002)

Yashiv, E.: U.S. labor market dynamics revisited. Scand. J. Econ. 109(4), 779-806 (2008)

Sandra Schaffner studied Industrial Engineering (Diplom-Wirtschaftsingenieurin) with a specialization in empirical economic research at the Technical University of Darmstadt. She has been working since April 2005 at the research division "Labor Markets, Education, Population" of the RWI as a research assistant. Sandra Schaffner received her PhD degree from the Ruhr-University of Bochum (Prof. Dr. Christoph M. Schmidt, PhD). She focuses on applied labormarket econometrics especially compensating wage differentials, labor-market dynamics, and evaluation of labor-market reforms. e-mail: sandra.schaffner@rwi-essen.de 